TITLI: NUCLEAR REACTOR POWER FOR AN ELFCTRICALLY PO'UERED TRANSFER VEHICLE

autmom(s): L. Jaffe, R. Beatty, P. Bhandari, E. Chow, W. Deininger, R. Ewel1, T. Fuijta, M. Grossman, T. Kia, B. Nesmith, T. Newell, C. F. Shih, J. Spanos, J. Stallkamp, J. Stevens, J. Stultz, A. K. Wanchoo, L. White, Jet Propulsion Laboratory; C. Bell, D. Carlson, J. Metzger, S. Voss, Los Alamos National Laboratory; and $H$. Bloomfield and $J$. Heller, NASA Lewis Research Center

SUDMITEO ro: Presented at the 19th AIAA/DGLR/JSASS International Electric Propulsion Conference, May 11-13, 1987, Colorado Springs, CO.

\title{
DISC 1.AIMER
}

\begin{abstract}
This repurt wiss preputed as an ilcount of work spoulsored hy in apency of the l/nited Slutes

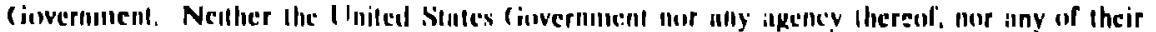

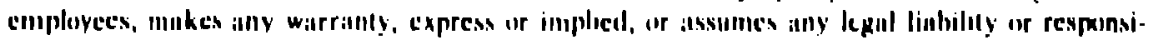

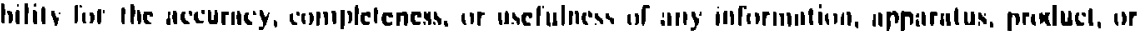
prexess disclesed. or represents that its use woulal mol infringe privitely owned rights. Refer-

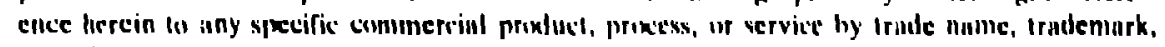
munufuclurer, of otherwian deres not necess:trils constilute ur imply its endursement, reconl. mendulion. or fuvoring by the Inited Silutes fiuvernment or uny ipency therewr. The views

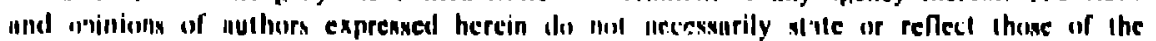
Ilniteal situtes (itovernment or uny Hgency :hereul.
\end{abstract}

\section{MASTE?}

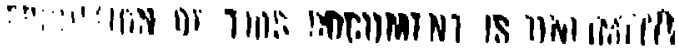




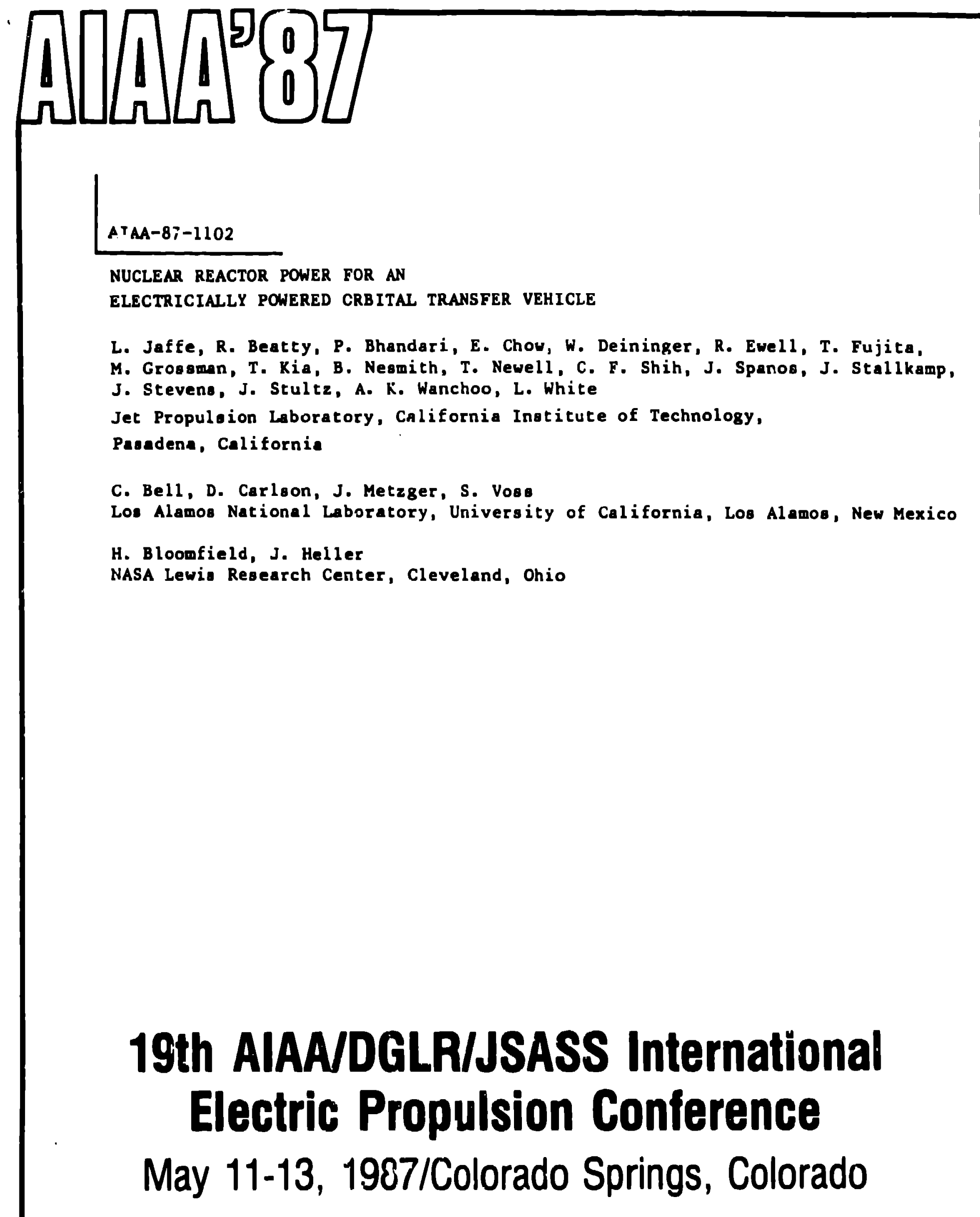

For pormiealon to copy or republleh, contect the Amoricen Inattute of Aoronautles and Astronautles 1623 Broadu sy, Now York, NYY 10018 
L. Jaffe, R. Ber'ıv, P. Bhandari, E. Chow, W. Deininger, R. Evell, T. Fujita, M. Grossnun, T. Kia, B. Nesmith, T. Newell, C. F. Shih, J. Spanos, J. Stallkamp, J. Stevene, J. Stultz, A. K. Wanchoo, L. Whit Jet Propulsion Laboratory, California Institute of Technology, Pasadena, California

\author{
C. Bell, D. Carlson, J. Metzger, S. Voss
}

Los Alamos National Laboratory, L'inersity of California, Los Alamos, Neu Mexico

H. Bloomfleld, J. Heller

NASA Leuis Research Center, Cleveland, Ohio

\section{Abseract}

To help desermine the systems requliensing for a 300-kWe apace nuclear reactor power system, a mission and spacecraft have been examined which utbize electric propulaton and this nuclear reactcr power for multiple transfers of cargo between low Earth orbit (LEO) and geosynchronous Earth orbit (GEO). A propulsion gystem employing ion thrusters and xenon propellant was selected. Propellant and thrusters are replaced after each cortle to GEO. The mase of the Orbital Transter Vehicle (OTV), empty und dry, is $11,000 \mathrm{~kg}$; nom Inal propellant load Is $5,000 \mathrm{~kg}$. The OTV operates between a circular orbit at $925 \mathrm{~km}$ altitude, 28.5 deg Inclination, and GEO. Cargo to brought to the OTV by Shuttle and an Orbltal Maneuvering Vehicle (OTV); the OTV then takes it to GEO. The OTV can also bring cargo back from GEO, for transfer by OMV to the shuttle. OTV propeliant Ia resupplied and the lon thrueters are replaced by the OMV before each trlp to GEO. At the end of misaion life, the OTV's electrlc propulsion Is used to place it in a hellocentric orblt oo that the reactor wlll not relurn to Earth. The nominal cargo capablilty to CEO Is $3000 \mathrm{~kg}$ with a tranalt $t$ ime of 120 days; $1350 \mathrm{~kg}$ can be traneferred In 90 days, and $14,300 \mathrm{kB}$ In 240 Jays. There capabllitles can be ronalderably increased by using separate shuttle launches to bring up propellant and cargo, or by ihargling to mercury propellant.

Introduct ton

The sp-ion Project was establlahed co develop and demoniliate fealblllty of a clase of upaca reactor power ayeteme (SRPS) that produce electrical pnwer In the lese than $100 \mathrm{~kW}$ to $1 \mathrm{MW}$ range. To holp detnrmine ayntemp requlrements for the SRPS. a mlasion and apacecraft were examined whlch utllize this clane of nuclar reactor pouer and electric propulion to make many tennafera of (argo hetween luw Earth orblt (LEO) and genaynchronous Earth orblt

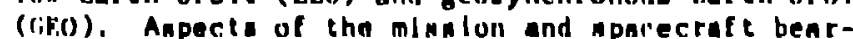
Inf on the power aymem vere the pilmary objectives of thin aludy. The ncudy was carrled out by the Syatemn Deolan Audle ranm of the sP-100 Profect. betalla are contalied In Ret. I. Annthor minalon

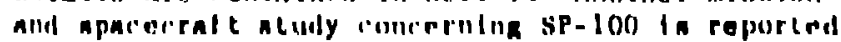
lil Knl . 2

Prlor to the Inlthatlun at thla mtidy, jo0 kHe

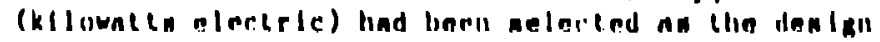

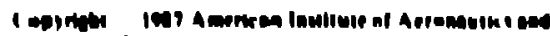

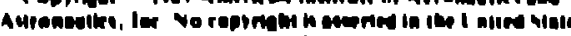

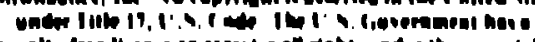

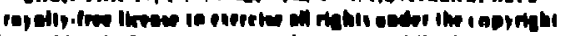

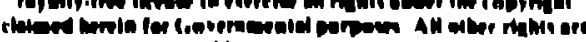

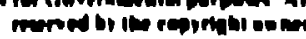

power level for development and ground tes: of key portions of an SRPS. To maximize applicabllity of the study to the planned SP-100 effort, 300 kHe was agsumed as the power level for the apacecraft. (Af tei the study was completed, the design level vas changed to $100 \mathrm{kWe}$.

Important misalon requirements vere:

(1) The OTV shall perform 10 corties between I,E) and GEO, elght of these carrying cargo from LEO to GEO, and two carrying cargo from GEO to LEO.

(2) The translt time from LEO to GEO bhall not exceed 120 dayo.

(3) The cargo carried to GEO, and the propellant required for the oTV corte. shall be within the capability of a r'ngle Shutcle Orbiter.

(4) If an Intermediate sage is needed between the Shuttlo and the OTV, propellant for the Intermed!ate stage shall be Included in the aingle shuttle payload mentloned.

Spacecraft functional requirements Included:

(i) After deployment of flexible elements of the power iystem, the acceleration pruvlded by the electric propulation eystem is the maximum that muat be withstood by the OTV.

(2) Polnting ansle eccuracy thall be $\$ 5$ des.

(3) Launch of all mieston eloments by the Shuttle Is asaumed. (Titan 4 lrunch was latar al oo consldered, )

$$
\text { Spar icraft Syeteme }
$$

Power

The power mource to a lud-npectrum reactor fueled wh UN and cooled w'lli ! lquld llthlium. A shleld ahadowa the reat of the npacrecratl fiom reactor radiction and an extendabia boom incther reduces the dose. Pumped lithlum heats one rid of a set of thermoelectrir olementa madn of sil-cie doped wlih Gap. Waste heal from the ribld mad of the thermelectrica Is remiyad hy heat pipen and radiated to mpace. Filectilcal power prislued ly the thermolectrict In inditloned and del iverind bu

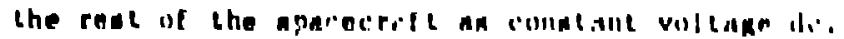

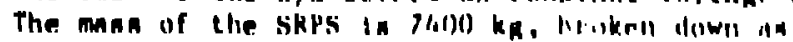
mhom In Tuble I.

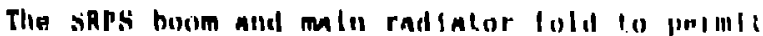

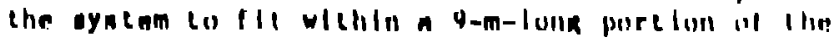

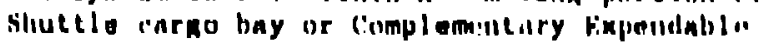

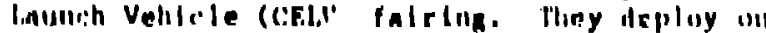

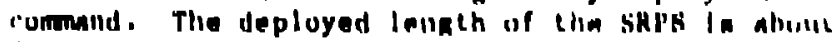
$24 \mathrm{~m}$ alld will ahout $20 \mathrm{~m}$. l'in llinemal rallentlill

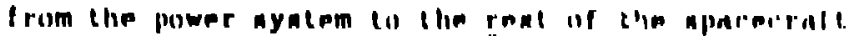
In 1 imlend to I nun $\left(1.4 \mathrm{~kW} / \mathrm{m}^{2}\right)$. Tlie Skl's In

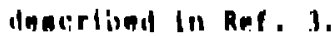


Table 1. Spacecraft Mass Ereakdown

\begin{tabular}{lr}
\hline \\
SRPS \\
Ragctor & $\mathrm{kg}$ \\
Shield & 1,650 \\
Heat transport & 700 \\
Power conversion & 1,450 \\
Heat rejection & 775 \\
Sygtem concrol, power & 1,440 \\
conditioning and digtribution & 950 \\
Structure and mechanisms & -420
\end{tabular}

MISSION MODULE

Communications, command,

attitude control

CARGO BAY

Structure $\quad 500$

Skin

Cargo Interface Ixtures

PROPULSION

Electric Propulsion $\quad 2,995$

Propellant Tank $\quad 480$

TOTAL, Mry and Empty

PROPELLANT (Xenon)

Total, with Prope!lant, Errpty

CARGO

Total, with Propellant and Cargo
110

$-100$

$k \mathbf{g}$

(a)

10,820

5,040

15,960

5,990

21,850

\section{Propulsion}

Electric propulgion characteristics used in the study were limited to those considered to provide low or moderate developmental rlst: for the 1995 time period. They are summarized in Tables 2 and 3. lon thrusters and xenon propellant were selected. Alternatives considered vere reslstojets, arcjets, and ion thrusters with mercury propellant. It was found that the performance of resistojets and ammonia arcjets was too low to bring any cargo to GEO within the misetion constraints of a single Shut le launch for cargo and propellanta. With hydrogen arcjets, the Shut le cargo bay would be almost filled by the hydrogen tank, Leaving i: idequate room for the cargo meani for Geo. Mercury Ion thrutera would provide somewhat better performance than xenor, but there are possible Shutcle safety and environmental iseues agsoclated with uring mercury.

The characteriutica asaumed for electric propulsion Included a minimum In with xenon of $29,400 \mathrm{~N}-\mathrm{s} / \mathrm{kg}$ ( $3000 \mathrm{lbf}-\mathrm{s} / \mathrm{lbm})$ and a lifetime of 5000 hours for ion thrusters. Thls necessitates replacement of the thrustera after each sortie to GEO.

\section{Other Syetems}

The spacecralt mission module contains communlcatlons, command, data handling, and attitude control equipment. Small low-galn and medium-gain antennas are provlded. Communiration 1. via TDRSS or another atellite when the OTV It relatively low, direct to Earth when orbit geometriea are inappropriate for satellitesatellite communleation.

Tabic 2. Electric Propulsion Characterictlce Astumed (TIme Perlod: 1995-2000)

Arc Jets

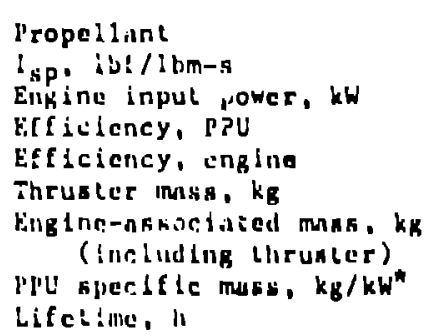

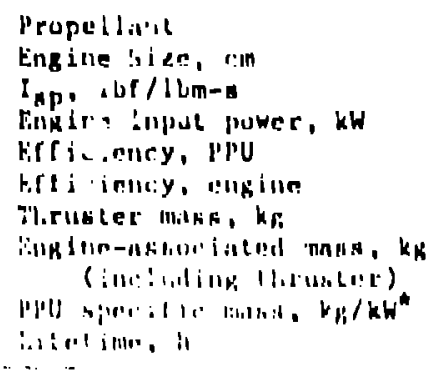

\section{lon Thrublers}

$\mathrm{N1} 3$
1.000
100
0.96
0.45
38.8
150
1.4
1,000

$H_{2}$
1,500
100
0.96
0.54
38.8
150
1.4
1,000

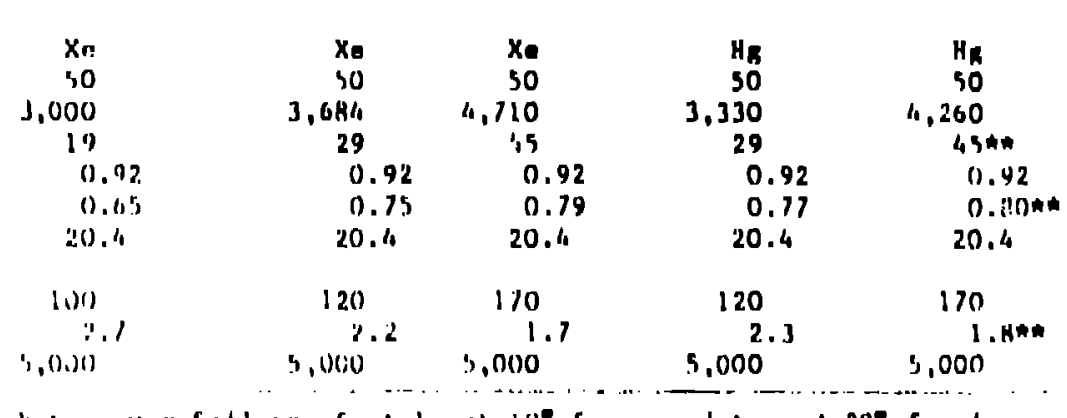

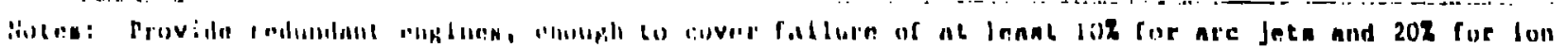

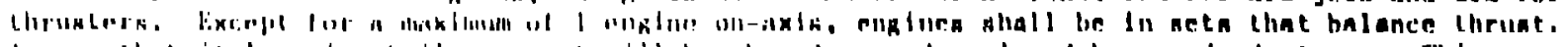

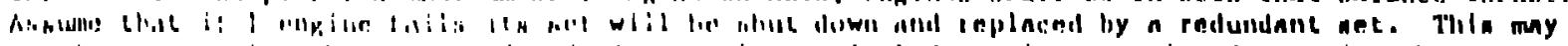

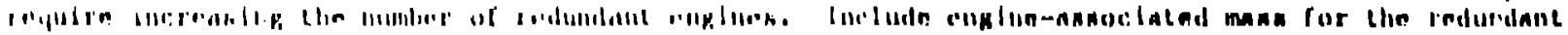
alitilen.

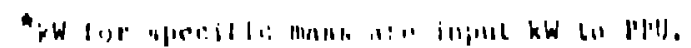

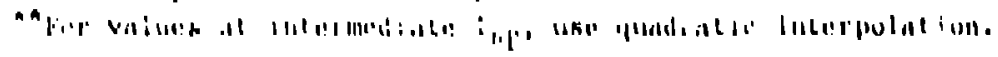


Table 3. Tankise and Plumbing Mass Relationshipsa

\begin{tabular}{|c|c|c|}
\hline Propeliant & $\begin{array}{l}\text { Propel lant } \\
\text { Mess, mp } \\
\text { kg }\end{array}$ & $\begin{array}{c}\text { Tankage and } \\
\text { Plumbing Mass } \\
\text { kg }\end{array}$ \\
\hline $\begin{array}{l}\mathrm{NH}_{3} \\
\mathrm{NH}_{3} \\
\mathrm{~K}_{2} \\
\mathrm{Xe} \\
\mathrm{Hg}_{8}\end{array}$ & $\begin{array}{r}5,000-18,300 \\
18,300-22,000 \\
5,000-13,000 \\
5,000-22,000 \\
5,000-22,000\end{array}$ & $\begin{aligned} 120 & +0.173 \mathrm{~m}_{p}+2.28 \mathrm{~m}_{\mathrm{p}}^{2 / 3} \\
1020 & +0.198 \mathrm{~m}_{\mathrm{p}} \\
610 & +0.493 \mathrm{~m}_{\mathrm{p}} \\
52 & +0.075 \mathrm{~m}_{\mathrm{p}}+0.154 \mathrm{~m}_{\mathrm{p}} 2 / 3 \\
150 & +0.020 \mathrm{~m}_{\mathrm{p}}\end{aligned}$ \\
\hline
\end{tabular}

aData for $\mathrm{NH}_{3}, \mathrm{H}_{2}$, and $\mathrm{Xe}$ are from B. Palaszweski.

Horizon and aun gensors are used for attitude control. Attitude control torque is provided by control moment gyros. These are unloaded by interact Ion with the Earth's magnetic field and by gimbaling or throtting of the propulsion thrusters. Aticude clanges will be relatively slow.

\section{Conf iguration}

Three candidate OTV configurations (Fig. la,b,c) were evaluated. In one (Fig. la), propulaion thrut is perpendicular to the boom of the power ystem. This necessitates a very long boom exiension to poeition the center of gravity properly. As a reault, the power cable length, mass, and losces are excesslve. The other two configurations (Fige, lb and lc) place the thrust vector along the boom. They have the propulsion oystem at the and of the spacecraft furthest from the reactor, and adjacent to the cargo bay. These configurations differ primarliy in how the carbo la loaded in the OTV cargo bay, from the ylde or fron aft. Side loading (Fig. Ir) was selerted to maximize commonallty of cargo literfaces with those used In the Shutlle. If, huwever, IIlan 14 Is to be useu to launch the cargo golng to GF, commonallty with the Tltan cargo Interface d more important and the aft-loadlng oTV conflgurallon ( $F \mid g$. Ib) would be preferred.

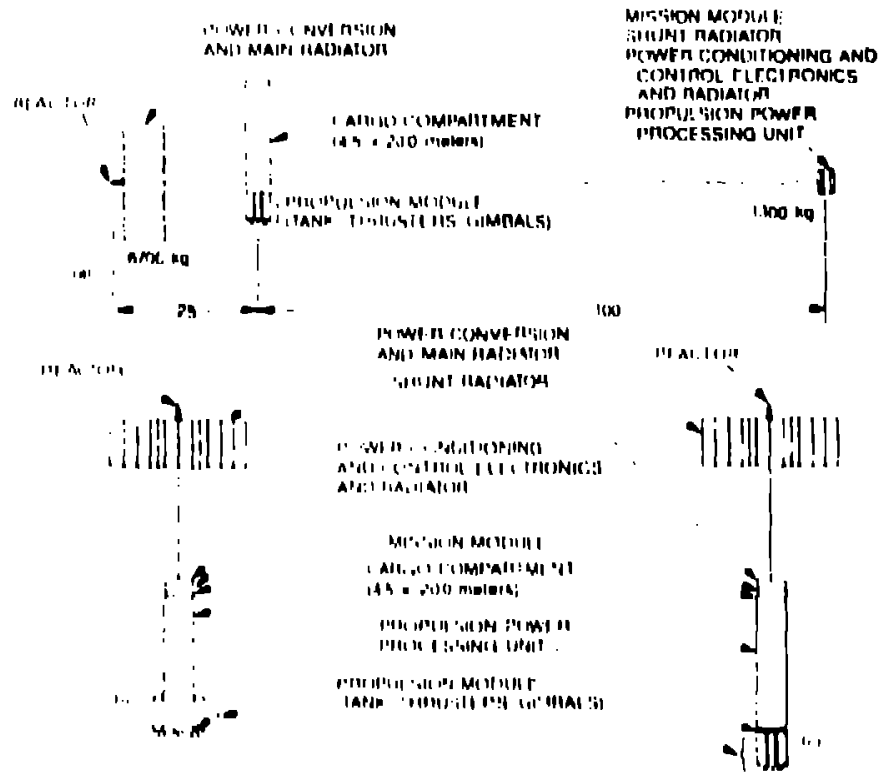

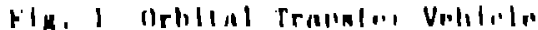

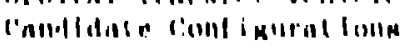

The selected configuration is $50 \mathrm{~m}$ long when deployed (F1g. 2). Its cargo bay is $4.5 \mathrm{~m}$ in diameter, the same as the Shuttle cargo bay, and its length is $20 \mathrm{~m}$, ac compared to $18.3 \mathrm{~m}$ for the Shuttle cargo bay. These dimensions were chosen to provide room for any cargo that can be carried by the Shuttle, plus an Orbital Maneuvering Vehicle (OMV), to be used for operations in GEO. The OTV cargo bay structure folds to fit in the shuttle for launch. The OTV mass, empty and dry, is $11,000 \mathrm{~kg}$; Table 1 gives a breakdom. $5000 \mathrm{~kg}$ of xenon propellant are normally carrled for a sortie to GEO.

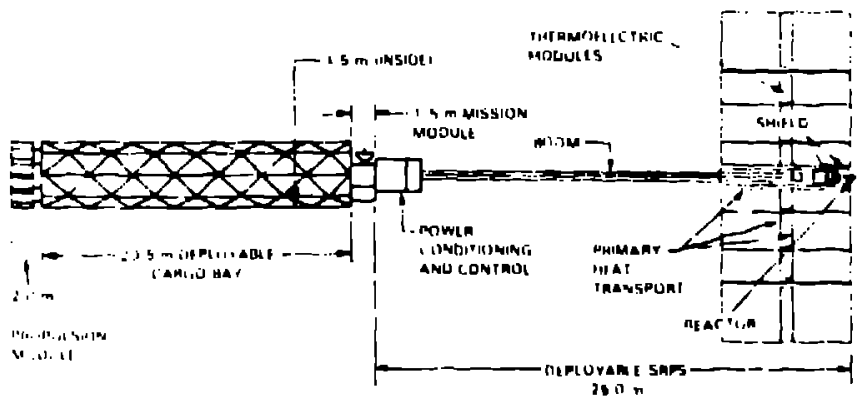

Fig. 2 Orbltal Tranefer Vehicle Details

\section{Mission Profile}

The OTV is op'erated on!y at a!titudes of $925 \mathrm{~km}$ and above. Th1 conetraint was assumed to ensure an nrbital lifotime of at least 300 years for decay of radioactivity if a spacecraft malfunction thould occur. (A decision on uperation of the reactor at lower altitudes is pending.)

The Shut te cannor deliver subatantlat payloade to an alt ltude of $925 \mathrm{~km}$. A chemical upper atage is needed to place the OTV In Ita operating orblt and, ubsequently, to brlng cargo, propellant, and replacoment thruaters to the OTV. Expendable -tages and an OMV were coniderec. The OMV was chosen because It can also be used to Install and remove carso, refuel the OTV, replace thrusters, and provide other needed function!. .

Twelve scenarlos vere congldered for placing the OTV In operatlonal orblt and then traneferring cargo between Earth and GEO. Criterla used to evaluate the scenarios Included the resultant OTV performance, this number of shultle launches requlred, the orbltal operationa requlred, and nuclear eafety.

The selected acenarlo is as Collnws: An Inltal shuttle flight launchea the folded OTV, lese propulalon, plua an attached OMN (Fig. 3). (The OTV propulgion module lo not carrled because of Ineuffletell room in the shutcle.) The OTV and OMV are plared ln a clrcular orbla at $27 \mathrm{~h} \mathrm{~km}$ altlude alil 28.5 des Inclinatlon. The oTV rargo bay depluyn on radlo rommand. Fixtra vehlcular uclivlty (EVA) In uned to lanlall neabllienra In the cargo bay atruiture and plare a thermal blankel arounds the buy. The iMV then laked the otV to $925 \mathrm{~km}, 28.4$ deg. Thre sRPs loum In deployed and

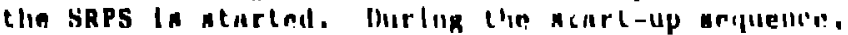
SRPS conlanen Clinw and Clir SARS maln radlentur

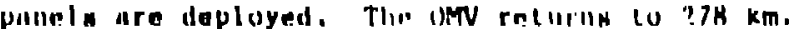

The wecund shutcle lanmeh brlings up $1027 \mathrm{~km}$

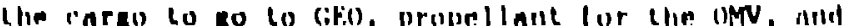

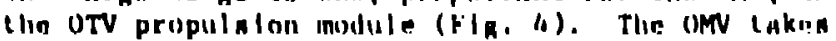


the cargo and OTV propulsion modu's to $925 \mathrm{~km}$ and transfers them to the OTV. The OMV returns to $278 \mathrm{~km}$. The OTV brings the cargo to GEO, places it there, and returns to $925 \mathrm{~km}$. Subsequent flights are similar, except that iristead of the OTV propulsion module, replacement OTV thrusters and propellant may be brought to the OTV. Propellant 1. transterred and thrusters replaced by the OMV. Table 4 glves a mass breakdown for the various Shultie payloads.

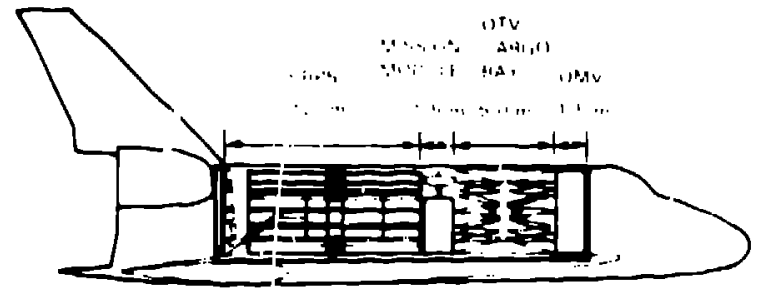

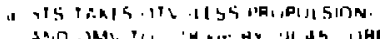

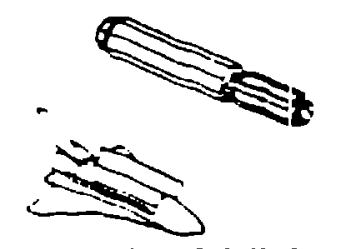

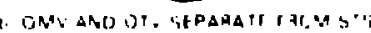

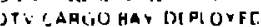

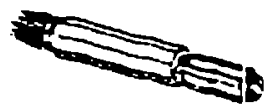

2

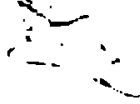

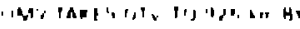

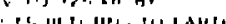

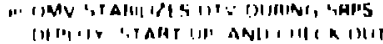

Fig. 3 Placing UTV in Orbit, First Shutele Flight
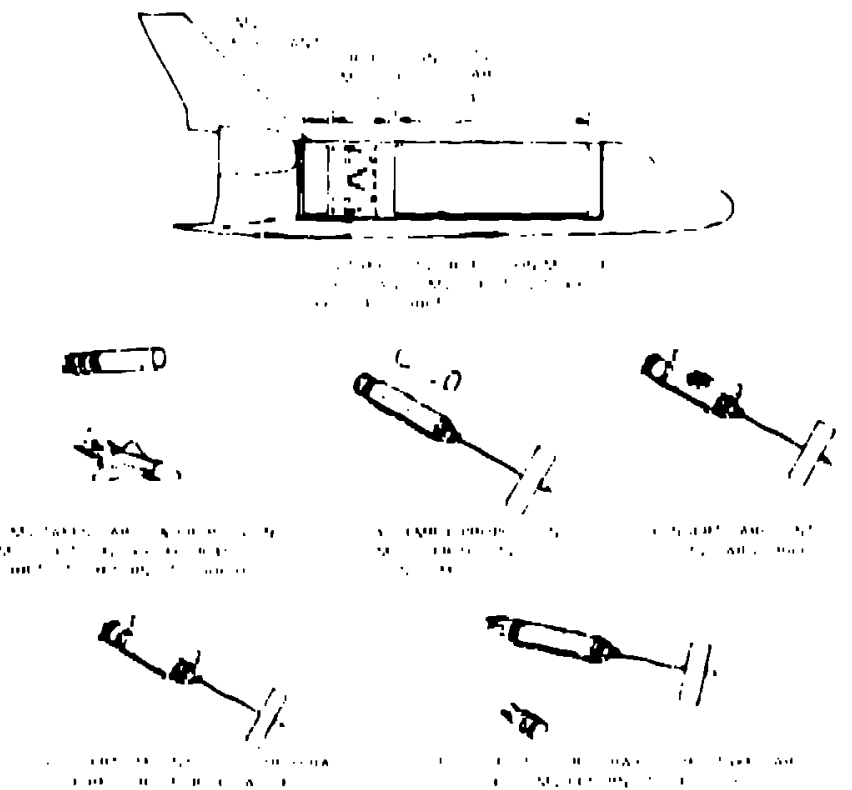

FIg. "Bringlus Cargo In rito, serond shut le Flight. (In sulineifuelle fIIshls, Shutele and OMV may brling up propelliant alld replaceinent thrustire for loTV, rather tinn coinplete propulatuil mudule.)
When eargo is to be brought down from GEO, the OTV carries an OMV to GEO. The OMV rendezvouses and dockg with the Largo, then places it in the OTV cargo bay. The OTV takes the cargo down t=925 km, and an OMV then brings it to Shuttle orbit.

A Titan 4 could be used in place of Shutcle to launch the cargo, with some decrease in the mass that can be cransferred to GEO. The old OTV thruaters and empty propel lant tanks could be jettisoned instead of being returned to Earth. Because of the EVA planned for installation of Gtructural gtabilizers, a Shutcle would be needed for the launch of the OTV Itself, unless c. cargo bay structure vith self-deploying stabilizera can be designed.

At the end of mission, the OTV is djsposed of by uaing ita electric propulston to take it to a heliocentric orbit. (Tranafer from GEO to hellocentric orbit requirea much leos propellant than a return flipht from GEO to LEO.) The reactor is then turned of by ground command, backed uf by an on-board clock.

\section{Interactions with Shuttle and Orbital Maneuvering Vehicle}

Flgurea 3 and 4 show apacecraft elements - towed in the shuttle Orbiler cargo bay. Structural support of the SRPS In the Shuttle bay 1. described In Ref. 5 . The OMV, launched with it, 1. supperted per the standard Shut le/OMV Irterface. The OTV miseton module and the folded OTV cargo bay are between the SRPS and the OMV and are supported by them. The OTV propulaton module, carrled on the aecond Shuttle launch, can be mounted to the Shuttle Orbiter bay keel and allie. The xenon propellant of the OTV will have to be vented or refrigerated whlle in the shutele.

The OrV plays an eusentlal role in tho celected ecenarlos, uerving a " "tender" to the OTV "ohlp". Key functiond Include:

(1) Intelal. tranafer of the OTV from shuttle orblt to $1 \mathrm{t} .925 \mathrm{~km}$ operat lonal orblt.

(2) Bringing cargo from Shutt le to the OTV and Incerting lt in the OTV cargo bay.

(3) Bringlns che OTV propulsion module, propellant, and replacement thrusters from the shutcle to the OTV, and attaching or transfarting them to the oTV.

(14) Pleking up cargo In GEO and placing it in the OTV cargo bay, and absequently tranifering the carno from the OTV at $925 \mathrm{~km}$ to Shuttle orblt.

(5) Bringlng usad propulaion tanke, thrusters, and propulson modules Irom the OTV back to the shuttle for aubsequent refurblahment and re-une.

Plail for the omv call ler a number of capabllilles to be Incurporated over a perlod of tlme (Ref. 4). Anong the OMV capablllilles necded for the OT biacion are:

(1) Resupply and tranofer of expendable flulda; sacecraft bervicing and module replacement, Inrluding placlng cargo In the OTV cargu bay and removing carko from it.

(2) Abllity to operate in Gro.

(3) Abllity to rondesvous and dock vith the OTV whlle the OMV Is carrylng rargo. 
Table 4. OTV Performance Summary

\begin{tabular}{|c|c|c|c|}
\hline Desig: & $\begin{array}{l}\text { Transit } \\
\text { Time, Days }\end{array}$ & $\begin{array}{l}\text { Cargo Deliverable } \\
\text { With Xenon } \\
\text { Propellant }\end{array}$ & $\begin{array}{l}\text { to GEO, kg } \\
\text { With Mercury } \\
\text { Propel lant }\end{array}$ \\
\hline $\begin{array}{l}\text { Selected Design } \\
\text { OMV initially at } 278 \mathrm{~km} \\
\text { OTV initially at } 925 \mathrm{~km} \\
\text { Single shuttle launch for cargo, propellanto, } \\
\text { and thrusers } \\
\text { I } \text { ap limited to lou to moderate rick }\end{array}$ & $\begin{array}{r}90 \\
120 \\
240\end{array}$ & $\begin{array}{l}1,350 \\
6,000 \text { (Basel ine) } \\
14,500\end{array}$ & $\begin{array}{l}3,100 \\
8,400\end{array}$ \\
\hline $\begin{array}{l}\text { Ion engine efficlency increased } 5 \% \\
\text { Ion thruster lifetime increased from } 5000 \text { to } 7000 \mathrm{~h}\end{array}$ & $\begin{array}{r}90 \\
120 \\
240\end{array}$ & $\begin{array}{r}2,300 \\
7,200 \\
14,700\end{array}$ & $\begin{array}{l}4, i 00 \\
9,700\end{array}$ \\
\hline Low lon engine I ap (high development risk for 1995) & $\begin{array}{r}90 \\
120\end{array}$ & $\begin{array}{l}2,750 \\
8,100\end{array}$ & 5,600 \\
\hline $\begin{array}{l}\text { Low I and } 2 \text { propellant canks, one discarded near GEO } \\
\text { Luw } I_{\text {an }} \text { and } 5 z \text { increase in engine efficiency }\end{array}$ & $\begin{array}{r}90 \\
120 \\
90\end{array}$ & $\begin{array}{l}3,800 \\
8,200 \\
4,200\end{array}$ & 7,300 \\
\hline Lov Iap and two Shuttle launches & $\begin{array}{r}90 \\
120\end{array}$ & & 5,900 \\
\hline Two shuttle launches & $\begin{array}{l}240 \\
360\end{array}$ & $\begin{array}{l}23,200 \\
28,500\end{array}$ & 26,100 \\
\hline $\begin{array}{l}\text { Two Shuttle launcheo, hydrogen arcjets, high Isp } \\
\text { (high development rigk for } 1995 \text { ) }\end{array}$ & 240 & \multicolumn{2}{|l|}{2,900} \\
\hline
\end{tabular}

Note: Cargo mased for alternative designe are listed only if greater than those for the eelected design and less ambitious alternatives, at a given cransit $t$ Ime.

(4) Ability to place italf in the oTv cargo bay and to remove leself from the bay. Additlonal tankage beyond that planned for Inltal OMV capabllity will alac be needed.

\section{Environment and Payload Accomodatione on the OTV}

The maxlmum radialion doop dellvered to the cargo from the nuciear reactor during a 120-day orbltal tranefer will be leas than $5 \times 1.0^{3}$ rad and $5 \times 10^{l l}$ neutrons $/ \mathrm{cm}^{2}$. The dose of lonial radiation expected from the natural environment Jurlng this tranifer, under average condlt lons. - 111 be abou: $1 \times 10^{6}$ rad thrugh $0.1 \mathrm{~g} / \mathrm{cm}^{2}$ of aluninum and $2 \times 10^{4}$ rad chrough $1 \mathrm{~g} / \mathrm{cm}^{2}$, An Insulating blanket surround Ing the cargo compartment of the OTV wlll protect OTV cargo from posalble contamiretion by the thrister -aisust, and will provide paselve temperature control. The OTV wIII a lo provide actlve heatine or cooling a requlred. Any power needed by the cargo wnlle lt is attached to the OTV can be easily aupplied. Commulcation between $t l$ e cargo and ground wlll be pr julded via the OTV'. cumminlcallon I Inks.

Aa mentloned above, the ITV cargo bay alse wll mateh that of the shile la and will provine addltiunal length to houms an OMV. Serletural Interfacing for cargo will ratch the Interfacing used by the cargo for mouncling in the shucle. (Alternatively. If cargo is lo be brought up pr'marlly by Titen 16 , the Interlare will be dealgued to match that unit for ritan 4.) Interface merhnnlamn and ronnectol a will be provided in the OTV cargo bay in perinle recelpt of the cargo from the OMV, Inclidelng making pluctrlial connectiona. These machanisme wil also permit releave of the cargo on comand, either tu the OMV or as an unattacned upacecraft.

\section{Performance}

Performance of the selected OTV deslgn la shorm in Table 4. Also shown ls the effect of vertous optione in tncreasing performance. The nominal cargo capabillty to GEO 10 $6000 \mathrm{~kg}$ with a transit time of 120 daye; $1350 \mathrm{~kg}$ can be transforred In 90 daya, and $14,500 \mathrm{~kg}$ in 240 days. The capability can be Incrensed to about $28,000 \mathrm{~kg}$ by using one Shuttle launch for the propeliant and another for the cargo, and oxtendlng the allowable transfer time. For spectal miselona the OTV propulalon module can be replaced in orblt with onte Incorporating mercury ion thruatere or ammonla arcjete, a deolred.

\section{Conclueisons} are

Findlige concerning the nuclear power system

(1) The elowed length of the puwer nystem is a deulgil driver for thin mlanlon.

(2) To maximlon the number of nIV nortlen to (E.o fur n kiven burnup in renctor fue 1 , it whould be posalble to redure rencecor autpue to a low level for weeks or minlhs. Thln would permll li OTV round trlps withln the sRrs dealgn 11 ita of 1 yenrm at fill puwer, 10 ianra total life.

(3) tharling the reactor In holioenterle urblt nhould bo comblated as une general mathod of dlapunlnat of il at, end of mlantur. 
some rinaings relevant to che UTV mission are:

(1) The minimum altitude to provide 300 years orbital lifetime is about $900 \mathrm{~km}$ for the spacecraft envisaged in this study. It may be destrable to keep the operacional OTV above this altitude ro allow time for fiesion producto to decay if the spacecrat should fall during operation.

(2) The OTV should be uned with an OrV. The OMV is recommended as the means of bitnging and tianaferring cargo, propellant, and replacement thruaters from Shuttle or Titan 4 to the OTV. When cargo is to be taken from GE'J to LEO, the OTV should bring an OMV to C5O to retrieve the cargo and place it in the UTV.

(3) Trangfer of cargo at the Space Station is unattractive for this mission becauge of the low capability of the shuttle to bring mase to the Space Station.

(4) The lifetime assumed for electric thrusters will necessitate frequent replacement of thrusters in orbit. Technlques which can be used by the OMV need 00 be deve'sned for orbital replacement of thrugters, propellant, And/or the elestris propulgion aystem.

(5) The design of the OTV should preferably provide full self-deployment in orbit without the need for manned asolstance.

(6) Method should be considered for retrieval of eplaning or tumbling spacecraft by the OMV.

\section{Acknowledgments}

William Gray and John Winslow contributed signif Icantly to work described in this report. This work was sponsored by the U.S. Department of Defense, the U.S. Department of Energy, and the National Aeronautles and Space Administration.

\section{References}

lJaffe, L. D., et al, "Nuclear Reacter Power for a Reusable Orbital Iranafer Vehicle," Jet Propulsion Laboratory, Pasadene, California, (in press).

2 Jaffe, L. D., et al, "Nuclear Reactor Power for a Space-Based Radar," JPL Publication 86-47, Jet Propulsion Laboratory, Pasadena, Caijfornia, Auguet 1986.

3Jaffe, L. D., et al, "Systems Aspects of a Space Nuclear Reaccor Power System," Jet Propulaion Laboratory, Passdena, California (in presa).

4"Orbital Maneuvering Vehicle (OMV) Requirements," Revision 3, Marshall Space Flight Center, September 1985 . 